\title{
A Study of the Management of Learners' Absenteeism in Schools Organizations in Nigeria
}

\author{
Ada Mary Juliana $^{1 *} \quad$ Arop, Festus Obun ${ }^{1} \quad$ Okute Agnes Lawrence ${ }^{2}$ \\ 1.Dept. of Educational Administration and Planning, University of Calabar, PMB 1115, Calabar, Cross River \\ State, Nigeria \\ 2.Dept. of Vocational Education, University of Calabar, PMB 1115, Calabar, Cross River State, Nigeria
}

\begin{abstract}
Learner absenteeism can be construed as an act of learner indiscipline which competes with or threatens specific school goals thus truncating school performance. The paper reflects on the issue of absenteeism in Nigerian school system with emphasis on management. It explores thechallenges and effects of student absenteeism and the benefits of absenteeism programs. It clarifies on the concept of an 'absentee' and a 'school manager' benchmarking on the Broken Window Theory (1982) by James Q. Wilson and George Kelling. Specifically, the study evaluated on basic guideline for forming and establishing a school absenteeism policydwelling on the issues of school management training which must be considered if school management must deliver on expected or established results.
\end{abstract}

Keywords: Learner's absenteeism, School organizational management, Principal leadership, Planning, Principal record keeping and success

DOI: $10.7176 / \mathrm{RHSS} / 9-18-01$

Publication date:September $30^{\text {th }} 2019$

\section{Introduction}

Absenteeism remains a major school problem. Learner absenteeism is not only a matter of school distress, it comes with a national proportion as well (UNESCO, 2018). School learners not showing up during school time presents a drain in human capital development. An effective educational system is one whichis based on the assumption that learners should attend classes as scheduled. In other words, a leaner can only gain full benefits of planned curriculum when he/she completes a good percentage of the assigned curriculum and this can only be done when the learner consistently makes himself/herself available for teaching time. An empirical study for a group of countries in Sub-Saharan African country found leaner absence rate of 18-27\% (Majgaard \& Mingat, 2012) comparedto that of advanced countries like the United States, Britain, Canada, Ireland, Switzerland, Germany and Israel at 4\% (OECD, 2013; Conry\& Richards, 2018).

Like in many countries globally especially emerging and developing ones, leaner absenteeism is an issue of concern especially in public schools.Public schools in Nigeria specifically suffer high rate of learner absenteeism with variations across states and between urban and rural areas. Leaners absenteeism ranged from a rate of $15 \%$ in urbancentres to $45 \%$ in rural communities (Fagbenle \& Elegbeleye, 2014; Ehindero, 2015; Amalu \& Abang, 2016; Mbagwu, Annorzie \& Ugwu, 2018). A recent survey tagged "2015 Education Data Survey" undertaken by the national Population commission in conjunction with USAID, Universal Basic Education Commission (UBEC), the Federal Ministry of Education and the National Bureau of Statistics revealed the following: In urban areas, $74 \%$ of children of primary school age attend school, compared to $57 \%$ in rural areas; the primary net attendance is highest in the South East region (81\%) compared to the North West region (43\%); only $49 \%$ of youth ages $12-17$ attend secondary school while $51 \%$ of males ages $12-17$ attend school, compared to $46 \%$ of females; the rate of primary school completion decreased from $88 \%$ in 2003 to $69 \%$ in 2015 and only $10 \%$ of the school population aged 15 years old and above have post-secondary education. A look at some of the statistics in 2019 shows that this trend has not changed.

It is apparent that when learner absenteeism is excessive, it impacts negatively on learning, truncates the teaching process leading to a decline in overall student's academic performance (Triado-Ivern, Aparicio-Chueca, Elasri-Ejjaberi, Maestro-Yarza, Bernardo \& Presas Maynegre, 2018). Students who attend school regularly are found to have better teacher-learner interaction, problem solving skills, peer relationships and language development compared to absentees (Rissanen, 2018). In most cases prolonged learner absenteeism discourages students from pursuing further education and finally leads to school drop-out (Hawken, Wayman, Wright, Fleming, \& Rolfe, 2018; Peguero, Merrin, Hong\& Johnson, 2019). It is also evident that teachers who spend time to review notes or re-take past lessons for the benefits of absentee students are often fatigue and it takes away needed time from students who already attend class regularly. Thus, absenteeism do not only have implications for absentees' academic outcomes, it truncates in — class planning of teachers and demotivates other students (Oluremi, 2013).

Chronic absenteeism is also found to have a positive nexus with social vices such as violence, substance abuse, prostitution, suicide, juvenile delinquency and early marriages (Fischer \& Argyle, 2018; Burdick-Will, 
Stein \& Grigg, 2019). It also has implications for school planning, school boards, parents/guardians, teachers and principals. It is a strong indicator of the type of adult that our school children turn out to be in future as well as the society these children live in. It frustrates the outcome of the Education for All (EFA) initiative and thus achievement of the Time Bound Millennium Development Goals and Nigeria's Vision 2020. School principals have long tried to mitigate the rate of leaner absenteeism and like Mohammed, Tolba \& Elmogy(2018) stated they often do not know the root cause of the issue at stake.Even for advanced economies, absenteeism is also a challenge. For instance a survey undertaken for US school principals showed that 71 percent of them indicated learner absenteeism as a crucial challenge in the school system (Balfanz, DePaoli, Atwell \& Bridgeland, 2018). A study undertaken by Leithwood and Sun (2018) stated that school leaders are the main factor of success if this phenomenon must be nipped and that the emphasis placed on learner absenteeism is a good indicator of the emphasis that a nation places on her educational system.

The authorsweremotivated to carry out this qualitative research for the following reasons:

1. The assumption that the high rate of failure and a decline in the willingness of today's youth to continue to advanced learning has a lot to do with learner absenteeism

2. Authors'personal experiences as educator for decades in primary school, secondary school, college of education and now University

3. Learner absenteeism has received minimum attention in comparison to teacher absenteeism in Africa and Nigeria specifically. This research thus is aimed at bridging the knowledge gap.

\section{Objectives of the study}

The study seeks to achieve the following objectives

1. Determine the factors that influencestudents' absenteeism in school institutions in Nigeria.

2. Guidelines for developing an effective absenteeism management framework for school organizations in Nigeria

It is the belief of the authors that the outcome of this paper based on an in-depth review of literature will provide school principals, policy makers and guardians on how learner absenteeism can be eliminated and the role that each of the stakeholder can play to improve teaching and learning in Nigerian schools. Thus, it is aimed at improving practice, informing policy and enriching knowledge base on leaners" absenteeism. After this introduction, comprehensive literature on the factors that influences absenteeism in schools is evaluated in section 2. Methodology is stated in section 3. Section 4 focuses on the guidelines for managing absenteeism in Nigerian school system while section 5 concludes.

\section{LITERATURE REVIEW}

Absenteeism defined

Learner absenteeism according to Wahid, Satter, Al Imran and Bhuiyan(2019) refers to consistent patterns of absence from school by a registered student. A student absentee is a student who is expected to be in school at specific times for specific periods and he/she is not there. A student is considered an absentee when he/she fails to report for school time and remain in school for a scheduled period regardless of the reason. This is devoid of approved school and national days of absence such as public holidays, strikes and weekends. It connotes a bridge of integrity on the part of the learner.

Lannegrand-Willems, Cosnefroy \& Lecigne (2012) asserted that learner absenteeism refers to being "absent in school with or without an excuse". To Balfanz and Byrnes (2012) absenteeism refers to both excused and nonexcused days of missing school. The authors stated the difference between three categories of absenteeism, i.e. moderate absenteeism, chronic absenteeism and Truancy. Though national data are not available on the absenteeism, moderate form of absenteeism refers to a situation when a learner misses $10 \%$ of total school attendance whether excused or non-excused and chronic absenteeism to when the rate of absenteeism doubles by another $10 \%$. Truancy on the other hand is considered a situation when a learner has up to $10 \%$ of unexcused attendance.More so, young children in primary school cannot be called truant since they are under parental guidance and cannot have missed school without the knowledge of their guardians.

\section{Factors that determine learner absenteeism in schools}

Out-of-school factors

This section reviews studies relating to out-of school factors that determine leaner absenteeism in schools. Wadesango and Machigambi (2011) conducted a research to determine the causes and structural effects of student absenteeism using three South African universities as case studies. Using the survey research design, data were collected through interviews and self-administered questionnaires. The result of the analysis revealed that in-school factors such as lack of interest in subject matter, poor teaching strategies by lecturers, unfavourable infrastructure for learning and poor student-lecturer relationship were the main determinants of student absenteeism. 
Ehindaro (2015) study for 175 students across selected schools cutting across three (3) senatorial districts in Ondo state Nigeria posits that peer-related and student psychological relate factor were the main determinants of truancy among students.

Demir and Karabeyoglu (2016) investigated factors associated with absenteeism among students in high schools. The authors made use of self-reported questionnaire to abstract data from 581 students from 9 th to $11^{\text {th }}$ grade. Three scales were used to assess three possible factors that might likely lead to learner absenteeism: The School Attachment Scale, Comprehensive School Climate Assessment Scale dimensions and Quality of Life Scale dimensions. The findings revealed that students' negative assessment of the school environment accounts for 83 percent of the variance levels and commitment to school while parental factors only account for $22 \%$.

Mafa (2018) stated that a learner who experiences high rates of family related factors such as having parent with little or no educational background, unemployed mother and shortage of food shotages at home is likely to miss $10 \%$ or more of school year compared t their peers with more positive family related factors.

Sahin and Arseven (2016) carried out a research to determine the causes of student absenteeism and school dropout in primary, secondary and high school students in Duzce province. A semi-structured interview was used to obtain data from 64 principals of selected schools

Senyametor, Gyimah and Minadzi (2018) employed purposive sampling technique to select 34 students from Junior Secondary Schools 1-3 attending Felicomfort JHS at Amamoma in order to determine the factors affecting the pupils' absenteeism. The analysis of the data using Predictive Analytical Software (PASW) found a learner absenteeism prevalence rate of $71.4 \%$. The major in-school factor responsible for this rate of absenteeism was teachers' inability to care and find out from pupils the cause of their absenteeism

In-School Factors

Cook and Ezennne (2010) stated that the main causes of student absenteeism is related to school factors especially school curricula. A study by Seeley, Tombari, Bennett and Dunkle (2011) found a connection between school bullying and learner absenteeism. They stated clearly that if bullying can succeed in reducing a learner engagement in school work, it can also succeed in keeping the learner away from class.

On the part of McCrea, Pigott and Kelly (2013) what makes students avoid school is corporal punishment which breeds low self-esteem in student, engender relationship divided between students and teachers who then loose interest in coming to school.

In a search to determine the major causes of absenteeism among students Komakeck and Robert Osuu (2014) got a sample of 226 from selected schools of four districts (Serere, Ngora, Soroti and Kuni) in Uganda. The analysis of the data showed that absenteeism was majorly determined by the following out of school related factors: household work, personal disinterest in education, hunger during school or lack of meals, long distance from home to school, loss of parent or guardian. Only two in-school factors were mentioned which were sexual harassment and harsh punishment at school. Based on the findings the authors made a recommendation that the government of Uganda should improve the living standards and socio-economic capacity of parents.

Following a similar framework Komakeck and Osuu (2014) claimed that leaners stay out of school when they are sexually harassed.

In their study Amalu and Abang (2015) made use of multistage sampling to select 320 pupils in selected 16 primary schools across eight local government areas in Cross river state to determine the psychological implication for national development of school absenteeism. The authors established from their analysis that they major determinants of pupil absenteeism is financial constraints, illnesses and pampering from family members.

Ruiz, Mink and Aleman (2018) explained the major reason for leaner absenteeism is students out of school priorities.

In relation to out-of-school factors Mogashoa and Mboweni (2018) undertook a study among two selected primary schools who had a history of high rate of student absence based in Bohlabela district of Mpumalanga province Tebogo South Africa to determine the challenges and factors contributing to leaner absenteeism. The study collected data using in-depth interviews and focus group discussions. The study established that a contributory factor is lack of parental involvement.

Chaves-Barboza, Marín-Marín, Sarmento-dos-Santos \& Trujillo-Torrres (2019) analysis of selfadministered questionnaire found out that out-of-school and specifically family socio-economic factors like the lack of financial and emotion support from families are the main social variables that causes student absenteeism from mathematics classes.

These risk factors do have implications for program activities, policy and how they are implemented. An overview of the review shows that family and economic factors have more weight on absenteeism in relation to school and student factors.

\section{Broken Window Theory (1982)}

This paper is structured around the Broken Window Theory. The theory was a major principle for police 
operations in the United States during the 1990s and is even been used

Consider a building with a few broken windows. If the windows are not repaired, the tendency is for vandals to break a few more windows. Eventually, they may even break into the building, and if it's unoccupied, perhaps become squatters or light fires inside

today for neighbourhood crimes. The theory is accredited to James Q. Wilson and George Kelling work of 1982 tagged "Broken Window" which appeared in the Atlanticwhere they used broken windows as a metaphor to explain indiscipline and disorder in neighbourhoods (Wilson \& Kelling, 1982). The authors explained this phenomenon with the following:

The theory is based on the assumption that an occurrence of indiscipline or neighbourly disorder that is not checked will definitely give rise to further of its occurrences in the future. It posits that unchecked disorder breeds fear in the minds of ordinary citizens whose response becomes withdrawal. This withdrawals energizes the perpetuators of crime to do more and social controls which before then kept criminals in check becomes overpowered (Wolff \& Intravia, 2019). Thus, "if a broken window is left unchecked many more will follow". The broken window symbolizes that the neighbours do not care about their environment and have tolerated low forms of deviance. The idea is that there should be zero tolerance for low-level crime.

The theory has been applied in several areas to solve crime. Notable use of this theory was by New York police Commission William Bratton who built his notable "quality of life initiative" using this theory. This was a proactive initiative to crack down on social vices such as street salient street prostitution, disorderly behaviours, panhandling, youth congregating in street corner, drunkenness, youth moving in groups in the street without actually carrying out any economic activities and unsolicited services like car window washing (O'Brien, Farrell $\&$ Welsh, 2018). The belief is that nipping this type of crime will prevent them from blossoming into full-scale societal vice such as sex-trafficking, money laundering, murder and bank robbery. Applied to learner absenteeism, if one learner is absent from school and no valid reason is given and no constructive action is taken, very soon other learners will interpret this to be that the school do not really care whether they are present in school or not and they might soon follow suit. This will then escalate the phenomenon making it more difficult to manage.

\section{METHODOLOGY}

The paper makes used of qualitative research design. A qualitative research enables the research to explore factors that have capacity to influence a phenomenon (Flick, 2018). The qualitative research methodology inculcates a desktop research that requires in-depth study of various literature relating to a specific construct or group of such as on data bases, institutional websites, Internet search sites, books, journals and newspaper publications. Policy documents on civil wars and conflicts were searched. This research also involved an assessment of information gathered to examine trends and rates amongst three Sub Saharan African countries by a review of the trends in conflict patterns. Journals cited in this paper were mainly procured from peer-reviewed and international publications online using the English language. Journals which specifically related to leaner absenteeism were included. The Key words used in searching for materials included "Student absenteeism in Africa," "Student absenteeism in Nigeria," "Data on Student absenteeism in Nigeria," Causes of Student absenteeism, "UNICEF Guidelines on Students Absenteeism," The materials search were conducted in such a manner that articles only from 2010 to 2019 were included except in cases of historical analogy and theoretical framework.

\section{GUIDELINES FOR MANAGEMENT OF LEANER ABSENTEEISM IN SCHOOL ORGANIZATIONS IN NIGERIA}

The role that educational management play in any educational system cannot be over emphasized. Though the school manager gets different titles based on the level of school education the role and function still remains the same. In Nigeria, the primary school manager is referred to as a headmaster or head teacher, in secondary school he/she is called the principal, at the post-secondary level refereeing to colleges of education he/she is called a provost; for polytechnics he is referred to as a rector and at the university level he is called a Vice Chancellor. The school manager, whatever educational level is responsible for overseeing, directing and controlling of both human and non-human resources (Fasisi, 2011). Shute and Cooper (2015) stated that leaner absenteeism is a basic indicator of a failing school system; he stated that if leaners are consistently turning their backs on schools, it means educational planners should ask themselves the question of "what is wrong with the system of education?" and "is there something happening in our classroom and schools that makes students not show up for leaning?".

One of the main human resource that a school manager is expected to control are the students, pupils. A good manager is known by the product he/she produces in the market place. In the school system, the testament to a functional administrative or managerial system is the type of product it produces i.e. the students.Connolly, 
James \& Fertig(2019) stated that when educational goals are not met, the first point of call for any school will be the leadership. As such the school manager is seen as the most critical determinants of school success. The primary responsibility of the school manager is the pursuit of academic excellence using available materials and resources. This is made up of his techniques, beliefs, strategies and approaches to adhere instructional efficiency in this scenario a management of three forms of absenteeism: truancy (i.e. unauthorized and invalid absence); authorised and valid and authorized but invalid for whicheach require different forms of management.Absenteeism improvement programs have a penchant for getting results if teachers and other stakeholders stay committed to it. Absenteeism programs should have clearly defined goals which for one is to ensure that every leaner has access to full time education for which they are entitled.

A guideline for proper absentee management is detailed thus:

\section{Proper policies and systems}

To deal with learner absenteeism effectively, it is imperative that school managers have proper and clearly spelled-out rules, policies and procedures which can be communicated to all parties clearly and ultimately serve as a reference point when dealing with students as regards their absenteeism. Gottfried and Hutt (2019) stated that it is crucial for every school organization to have an attendance policy that can be described as formal, detailed and dress issues of failure to call in in cases of absences. This policy can be developed during a general meeting attended by various school stakeholders such as school governors, teachers, local government authority, parents, career counsellor etc. and the definition of regular school attendance conforms with this policy. The policy should clearly state what it deemed an "authorize absence" and what is not. The policy should have the following sections which should be clearly stated and explained:

- The Title of the Policy Document e.g. NGN Secondary School Student Attendance Policy

- Introduction and background: this introduction should state what the document is all about, the objectives of the policy

- School Attendance and the Nigerian Policy on Education

- Meaning of Chronic absenteeism, Authorized and Unauthorized Absences

- Procedure before authorized absence can be issued

- $\quad$ Procedure to deal with unauthorized absences

Zero tolerance policies should not inculcate measures that seek to expel students completely from the school systems as evidence have shown this more or less only encourages the leaners to stay away from the school environment. A research conducted by the American Psychological Association in 1990 shows that harsh punishment such as expulsion only encourages deviant behaviour and high rates of school dropout; and schools which adopt this kind of disciplinary measures are not any safer today than they were in the 1990s. Rather, school policies should inculcate more sophisticated approaches such as personalized learning, peer mentoring, development of learning communities, student counselling programs and subsequent follow-up.

- Summary and Conclusion

- Frequency Asked Questions (FAQs)

2. Rewards and incentive programs

Royer, Lane, Dunlap \& Ennis (2019) are of the opinion that people usually enjoy praise and recognition when they have done excellently or have improved on past deficiency as this helps in reinforcing good behaviour. School managers must necessarily accord recognition and or rewards for students and parent who support school policy. It is possible that individual behaviour will change for the better when incentive such as this is introduced. It will serve as a motivation to keep this behaviour so that they can be recognised in future. Recognition can be given for the following categories: most punctual students, the early bird students in keeping with total number of schools days as a percentage of the number of actual days that the students actually shows up. This is done by the following formula:

\section{$S A I=\frac{\text { Number of Days students actually attended school }}{\text { Total Number of School Days per term }}$}

Where:

$\mathrm{SAI}=$ school attendance index

In keeping with the foregoing Ginns and Begenry (2019) stated that these incentives programs should be consistent without fail as a recognised student is less likely to be absent from school.

\section{Management training}

Since school managers whether headmaster, principal, provost, rector or vi-chancellor are at the core of dealing with student absenteeism, they should ideally undergo training in this area. The training of these 
school mangers should be done in line with the following:

- Procedures and steps to identify occurrences of learner absenteeism

- Ability capacity to make recommendations after identifying patterns of learner absenteeism

- Ability to apply the appropriate corrective measures

- Ability to make statistically comparison that quickly denote patterns of absenteeism

- Disciplinary procedure acceptable in Nigerian National Policy on Education (NPE).

\section{Raise awareness among teachers and students}

- The students must be properly guided on their role in absenteeism the policy and rules governing learner absenteeism and the consequences of such behaviour

- Teacher should in turn be trained by school managers on the patterns of absenteeism how to understand these patterns and how to effectively report it

\section{CONCLUSION AND SUMMARY}

The ability to effectively manage absenteeism is an indication of effective management and the ability of a school manager to keep track of its internal control. As already established absenteeism is not only about a learner not showing up for school but inculcates other factors such as impacts negatively on learning, truncates the teaching process leading to a decline in overall student's academic performance as well as its positive nexus with social vices such as violence, substance abuse, prostitution, suicide, juvenile delinquency and early marriages. A school system that must be successful is one who manages its forms of absenteeism effectively. Thus, in addition to the above guidelines, the following recommendations are proffered:

1. The management of absenteeism must be done in such a manner that every stakeholder understands that the school takes absenteeism seriously

2. Cases of absenteeism must be dealt with speedily and proactively

3. The management of absenteeism must be done in such a manner devoid of any form of favouritism; the system must be consistent and transparent.

\section{References}

Amalu, M. N. \& Abdang, K. B. (2015). School absenteeism among primary school pupils in cross river state: psychological implications for national development. Global Journal of Educational Research, 15, 49-56

Balfanz, R. \& Byrnes, V. (2012). Chronic absenteeism: Summarizing what we know from nationally available data. Baltimore: Johns Hopkins University Center for Social Organization of Schools.

Balfanz, R., DePaoli, J., Atwell, M., \& Bridgeland, J. (2018). Great American High School Campaign: Reforming the Nation's Remaining Low-Performing High Schools. Civic Enterprises.

Balkis, M. (2018). Academic amotivation and intention to school dropout: the mediation role of academic achievement and absenteeism. Asia Pacific Journal of Education, 38(2), 257-270.

Burdick-Will, J., Stein, M. L., \&Grigg, J. (2019). Danger on the Way to School: Exposure to Violent Crime, Public Transportation, and Absenteeism. Sociological Science, 6, 118-142.

Chaves-Barboza, E., Marín-Marín, J. A., Sarmento-dos-Santos, A. P., \& Trujillo-Torrres, J. M. (2019). Student Absenteeism in Mathematics Lessons: Social Variables in the PGS of Namibe. Education Sciences, 9(2), 130.

Connolly, M., James, C., \& Fertig, M. (2019). The difference between educational management and educational leadership and the importance of educational responsibility. Educational Management Administration \& Leadership, 47(4), 504-519

Conry, J. M., \& Richards, M. P. (2018). The severity of state truancy policies and chronic absenteeism. Journal of Education for Students Placed at Risk (JESPAR), 23(1-2), 187-203.

Demir, K. \& Karabeyoglu, Y. A. (2016). Factors Associated with Absenteeism in High Schools. Eurasian Journal of Educational Research, 62, 37-56

Ehindero, S. A. (2015). Truancy among Public Secondary School Students. Implications for Counselling. Journal of Emerging Trends in Educational Research and Policy Studies (JETERAPS) 6(7): 331-338.

Fagbenle, A. O. \&Elegbeleye, A. O. (2014). Attendance Dilemma and its Effects on the Academic Performance of Secondary Schools' Students in Osun State, Nigeria. International Journal of Humanities Social Sciences and Education (IJHSSE), 1(4), 13-20

Fischer, S., \& Argyle, D. (2018). Juvenile crime and the four-day school week. Economics of Education Review, 64, 31-39.

Flick, U. (2018). An introduction to qualitative research. Sage Publications Limited.

Ginns, D. S., \&Begeny, J. C. (2019). Effects of Performance Feedback on Treatment Integrity of a Class-Wide Level System for Secondary Students With Emotional Disturbance. Behavioral Disorders, 44(3), 175-189.

Gottfried, M. A. (2019). Chronic absenteeism in the classroom context: Effects on achievement. Urban 
Education, 54(1), 3-34.

Gottfried, M. A., \& Hutt, E. L. (2019). Addressing Absenteeism: Lessons for Policy and Practice. Policy Analysis for California Education, PACE.

Hawken, L., Wayman, G., Wright, H., Fleming, J., \& Rolfe, J. (2018). Effects of School of Life Foundation Intervention on Grade Advancement, Dropout and Attendance: A Descriptive Study. Research Journal of Education, 4(12), 221-229.

Komakech, R.A. \&Osuu J.R. (2014). Students' absenteeism: A silent killer of universal secondary education(USE) in Uganda. International Journal of Education and research, 2(10), 10 417- 436.

Lacoe, J., \& Steinberg, M. P. (2019). Do suspensions affect student outcomes? Educational Evaluation and Policy Analysis, 41(1), 34-62.

Leithwood, K., \& Sun, J. (2018). Academic culture: a promising mediator of school leaders' influence on student learning. Journal of Educational Administration, 56(3), 350-363.

Mafa, D. (2018). Learner absenteeism in a rural, small town: a case study of Kogma Great Kai. Educor Multidisciplinary Journal, 2(1), 7-31.

Majgaard, K. \&Mingat, A. (2012). Education in sub-Saharan Africa: A comparative Analysis. Washington DC: The World Bank.

Mbagwu, M. I., Annorzie, H. I., \&Ugwu, A. A. (2018). IMPACT OF PARENTS'FINANCIAL LEVEL, PERSONALITY AND RESIDENTIAL AREA ON SCHOOL TRUANCY AMONG SECONDARY SCHOOL STUDENTS IN ABA. Journal of Professional Counselling and Psychotherapy Research, 1(1).

Mohammed, K., Tolba, A. S., \&Elmogy, M. (2018). Multimodal student attendance management system (MSAMS). Ain Shams Engineering Journal, 9(4), 2917-2929.

Nelson, J. (2019). Using PBIS Frameworks in Elementary Schools to Decrease Chronic Absenteeism.

O'Brien, D. T., Farrell, C., \& Welsh, B. C. (2018). Broken (windows) theory: A meta-analysis of the evidence for the pathways from neighborhood disorder to resident health outcomes and behaviors. Social Science \& Medicine.

Oluremi, F. D. (2013). Truancy and Academic Performance of Secondary School Students in Southwestern Nigeria: Implications for Counselling. International Journal for Cross-Disciplinary Subjects in Education (IJCDSE), 3(2), 1424-1428.

Peguero, A. A., Merrin, G. J., Hong, J. S., \& Johnson, K. R. (2019). School disorder and dropping out: the intersection of gender, race, and ethnicity. Youth \& Society, 51(2), 193-218.

Rissanen, A. (2018). Student Engagement in Large Classroom: the Effect on Grades, Attendance and Student Experiences in an Undergraduate Biology Course. Canadian Journal of Science, Mathematics and Technology Education, 18(2), 136-153.

Royer, D. J., Lane, K. L., Dunlap, K. D., \& Ennis, R. P. (2019). A systematic review of teacher-delivered behavior-specific praise on K-12 student performance. Remedial and Special Education, 40(2), 112-128.

Ruiz, I., Mink, J., \& Aleman, X. (2018). Truancy in High School. SPACE: Student Perspectives about Civic Engagement, 3(1), 3.

Senyametor, F., Gyimah, E. K., \&Minadzi, V. M. (2018). Factors Affecting Pupils' Absenteeism at Felicormfort Junior High School (JHS) in Cape Coast, Ghana. Journal of Education and Learning, 7(6), 138-149.

Simuforosa, M. \&Ngara, R. (2016). School non-attendance: a study of its causes among which school students in Masvingo district secondary schools, ZIMBABWE. IJRDO-Journal of Social Science and Humanities Research, 1(2), 27-48.

Triado-Ivern, X., Aparicio-Chueca, P., Elasri-Ejjaberi, A., Maestro-Yarza, I., Bernardo, M., \&PresasMaynegre, P. (2018). A factorial structure of university absenteeism in higher education: A student perspective. Innovations in Education and Teaching International, 1-12.

Wahid, Z., Satter, A. K. M., Al Imran, A., \&Bhuiyan, T. (2019, January). Predicting Absenteeism at Work Using Tree-Based Learners. In Proceedings of the 3rd International Conference on Machine Learning and Soft Computing (pp. 7-11). ACM.

Wilson, J. (2018). Q. \& KELLING, George L.(1982). Broken Windows: the police and neighborhood safety. Atlantic Montly (digital edition). Mar.

Wolff, K. T., \&Intravia, J. (2019). Broken Windows/Zero-Tolerance Policing. The Wiley Blackwell Encyclopedia of Urban and Regional Studies, 1-6. 